\title{
Effectiveness of Project-based Learning Model to Improve Students' Cognitive Skills
}

\author{
Iman Hermanto $^{1}$, Sarwi Sarwi ${ }^{2}$, Amin Yusuf $^{3}$ \\ \{imanhermanto2910@gmail.com ${ }^{1}$, sarwi_dosen@mail.unnes.ac.id ${ }^{2}$ \} \\ SD Negeri 2 Putat Korwil Sedong Cirebon ${ }^{1}$, Universitas Negeri Semarang ${ }^{2,3}$
}

\begin{abstract}
This study aims to describe the use of project-based learning model to improve students' cognitive skills after participating in the project-based learning process. This study employed a quantitative approach using experimental method. The design used in this study was non-equivalent control group design. This study was conducted at SD A, SD B, and SD C Cirebon with 105 fourth graders as the research subjects. The subjects, consisting of 72 students in the experiment group and 33 students in the control group, were selected using simple random sampling technique. The instrument used was test in the form of pretest and posttest. Students' cognitive skills were measured based on the improvement in students' learning outcomes by comparing the result of pretest and posttest. From the result, it can be concluded that project-based learning can improve students' cognitive skills of four graders for animal life cycle lesson. The average learning outcomes increase from sufficient to good category. Classical learning mastery increases from less good to excellent category.
\end{abstract}

Keywords: project-based learning, cognitive skills.

\section{Introduction}

Education is a life-long need. As time goes by, changes and development often occur in education, for example the development of Kurikulum Tingkat Satuan Pendidikan (KTSP) into the 2013 Curriculum which demands teachers and students to be actively involved in the learning process. Education must be directed to produce quality and competitive humans in the global changes and development. In addition, one of the education goals is to prepare students with analytical, problem-solving and critical thinking abilities so that they can perform at a higher level of thinking [1]. Considering the demand, efforts to improve the quality of education must be conducted comprehensively, one of which is developing Indonesian human resources completely, including aspects of morality, character, knowledge, competence, sports, arts, and behavior. It is in accordance with Law No 20 of 2003 on the National Education System Article 3 stating that national education is aimed at developing learners' potential so that they become persons imbued with human values who are faithful and pious to God, who possess morals and noble character, who are healthy, knowledgeable, competent, creative, independent, and as citizens, are democratic and responsible.

Improving education quality should be accompanied by strengthening character education for students to think critically and creatively, be able to communicate, collaborate, and compete in this 21 st century [2]. It is also in line with four competencies that students should possess in this 21 st century, called 4C (Critical Thinking and Problem Solving, Creativity, 
Communication Skills, and Ability to Work Collaboratively). Therefore, learning activities and learning environment must be able to provide support systems that build 21 st century skills.

The curriculum being implemented currently in national education system is 2013 Curriculum which emphasizes cognitive and knowledge aspects as well as developing attitude, knowledge, and skills. In accordance with the 2013 Curriculum, learning process which has been carried out should not only concern with delivering the materials but also with the students' involvement during learning and students abilities in completing projects [3]. Hence, teachers should be able to select the appropriate learning model. The model which best corresponds to this requirement is Project-based Learning (PjBL) model.

Project-based learning $(\mathrm{PjBL})$ is a learning model which engages students in a particular task and requires them to work together, autonomously and purposefully, toward the completion of a project, so it enables them to gain knowledge and life-enhancing skills [4]. $\mathrm{PjBL}$ allows students to solve problems through their active participation, which results in developing students' process skills. The core of PjBL is accomplishing a project, which refers to an act of creation over time and enables students to do a constructive investigation [5]. There are abundant benefits that teachers and students can get from PjBL. Through PjBL, connection with problems of real world is achieved, so students develop both cognitive skills and other abilities useful for their lives [6]. In addition, PjBL fosters the skills of critical thinking and question-posing of the students [7].

From the above elaboration, the writer intends to implement Project-based Learning (PjBL) in science learning in the fourth grade. PjBL model is expected to improve students' cognitive abilities as the writer considers students less have the abilities. Teachers only point out the achievement of curriculum demands and textual delivery instead of developing individuals and their learning abilities. This condition will not improve students' cognitive abilities and, as a result, the students' scores are not as expected. Most of students' learning outcomes do not meet the minimum learning mastery criteria.

This study investigates the effect of $\mathrm{PjBL}$ on students' cognitive skills in science learning of four graders in several elementary schools. Cognitive skill is closely associated with knowledge, attention, memory, producing and understanding the language, problem solving, and decision-making [8]. The skill is considered essential for life, for example, it can determine how an individual solves problems, affect leader performance [9], and courage better education [10].

\section{Method}

This study employed a quantitative approach using experimental method, i.e. the method which tests the hypothesis of a cause-effect relationship. The population of this study was fourth graders of primary schools. This study was conducted at SD A, SD B, and SD C with 105 fourth graders as the research subjects. The subjects consisted of 72 students in the experiment group, and 33 students in the control group. The subjects were selected by using simple random sampling technique. This assumption was based on the school characteristics, including the same school accreditation, curriculum, total hours, and learning materials, as well as the score of science subject which is below the minimum learning mastery criteria. 
The instrument employed in this study was test, in the form of pretest and posttest to measure students' learning outcomes. Moreover, this study used Non-equivalent Control Group Design. The design is illustrated in Table 1 below:

Table 1. Research Design

\begin{tabular}{cccc}
\hline Class & Pretest & Treatment & Posttest \\
$\mathrm{E}$ & $\mathrm{O}_{1}$ & $\mathrm{X}$ & $\mathrm{O}_{2}$ \\
$\mathrm{C}$ & $\mathrm{O}_{3}$ & & $\mathrm{O}_{4}$ \\
\hline
\end{tabular}

Note:

$\mathrm{E}=$ Experiment Group

$\mathrm{C}=$ Control Group

$\mathrm{O}_{1}=$ Pretest score before treatment for the experiment group

$\mathrm{O}_{2}=$ Posttest score after treatment for the experiment group

$\mathrm{X}=$ Treatment using Project Based Learning

$\mathrm{O}_{3}=$ Pretest score of the control group

$\mathrm{O}_{4}=$ Posttest score of the control group

The research procedure consisted of three stages, those were preparation stage, implementation stage, and final stage. Preparation stage included (1) conducting interview and observation of fourth-grade teachers of state elementary school A, (2) preparing the research instrument, including questions for pretest and post test as well as lesson plan, (3) checking the validity of research instrument, (4) revising research instrument, (5) conducting try out of the questions in another school, which was elementary school B, having the same school accreditation "B", (6) analyzing the data of try out to investigate the reliability, difficulty level, and distinguishing power of each test item, and (7) using the questions to collect necessary data.

The second stage, implementation, consisted of (1) determining research schedule in line with the schedule of science learning, (2) providing pre-test to investigate the students' precondition, (3) carrying out learning activities with project-based learning, and (4) providing post test. Eventually, final stage comprised (1) giving score for pre test and posttest, (2) calculating the average students' learning outcomes, (3) calculating Standard Deviation, (3) checking data normality, (4) testing the hypothesis by using t-test formula, (5) investigating the impact of effect size formula, and (6) drawing conclusion.

The data collected on this study was students' learning outcomes in the pretest and posttest for science learning by implementing project-based learning model. The pretest data was used to investigate students' abilities at the beginning of the lesson before treatment, and the posttest data was used to investigate students' improvement after treatment. In addition, the research source was from learning outcomes of fourth-grade students in elementary school $\mathrm{A}$ and $\mathrm{B}$. The techniques of data collection in this study were measurement and direct observation technique, hence, the instruments of collecting data were test and observation sheet. To create an objective research instrument which can test the hypothesis, an analysis for the following instruments was needed: (1) lesson plan, (2) test, (3) validity, (4) reliability, (5) difficulty level, and (6) distinguishing power.

Several data analysis techniques were conducted to answer the research problems. In line with the first problem, which is the average of students' score by implementing project-based 
learning model in science learning of fourth grade in elementary school A and B, the following formula was used, see formula (1):

$$
\mathrm{Me}=\sum \text { fixi } \sum \mathrm{fi}
$$

To figure out the answer of the second problem, whether there is any effect of projectbased learning implementation on students' learning outcomes in science learning of fourth grade in elementary school A and B, the t-test formula was employed through several steps: The first one was calculating pretest and posttest score in the experimental class based on the scoring criteria. The next step was calculating the average score of pretest and posttest in the experimental class, see formula (2), calculating standard deviation of pretest and posttest result in the experimental class, see formula (3), testing the instrument validity by using Product-Moment Correlation formula, see formula (4), and testing the test reliability by using Kuder Richadson (KR-20) formula, see formula (5).

$$
\begin{gathered}
\mathrm{Me}=\sum \text { fixi } \sum \mathrm{fi} . \\
\mathrm{SD}=\sqrt{ } \sum f \mathrm{i}(\mathrm{xi}-\mathrm{X}) 2(\mathrm{n}-1) \\
R_{x y}=\frac{N \sum^{n} X Y-\Sigma^{n} X \Sigma^{n} Y}{\left.\sqrt{\left[N \sum X^{2}\right.}\left(\sum X^{2}\right)\right]\left[N Y^{2}-\left(\sum Y\right)^{2}\right]} \\
\eta_{t}=\left(\frac{\mathrm{n}}{\mathrm{n}-1}\right)\left(\frac{S^{2}-\Sigma \mathrm{pq}}{S^{2}}\right)
\end{gathered}
$$

\section{Result and Discussion}

The result of this study aims to investigate the effect of implementing Project-based Learning on the science learning outcomes of fourth-grade students in elementary school A and B. The total sample in this study was 105 students (72 students in the experimental group, while 33 students in the control group), each of them followed posttest and pretest. Pretest was conducted on May 7th 2019 during science learning and followed by all 105 fourth graders. The students answered the 20 questions of pretest in the form of multiple choice and short essay. The result of pretest and posttest of students' cognitive abilities is presented in Table 2 .

Table 2. The Result of Pretest and Posttest

\begin{tabular}{lcccccc}
\hline Type of Data & \multicolumn{3}{c}{ Control Group } & \multicolumn{3}{c}{ Experiment Group } \\
& Pretest & Posttest & N-Gain & Pretest & Posttest & N-Gain \\
Max Score & 90 & 90 & 0.50 & 85 & 100 & 1,00 \\
Min Score & 60 & 65 & -0.17 & 60 & 65 & 0,13 \\
Average Score & 71.9 & 75.2 & 0.12 & 72.7 & 85.8 & 0.50 \\
\hline
\end{tabular}


From the above table, the average score of students ' cognitive skills of the control group in the pretest was 71.9, while in the posttest was 75.2, and the $\mathrm{N}$-gain was 0.12 . Moreover, the average score of students' cognitive skills of the experiment group in the pretest was 72.7, while in the posttest was 85.8, and the $\mathrm{N}$-gain was 0.5 Considering the minimum learning mastery criteria of science learning in grade four, which is 72 , there were $30 \%$ students who met the criteria, while $70 \%$ students did not. The result also showed that the lowest score was 60 , and the highest score was 85 .

Moreover, the posttest was conducted by implementing project-based learning in science learning on May 9th 2019 involving 105 students. Based on the posttest result, students who met the minimum mastery criteria were $10 \%$ out of the total students. The lowest score was 65, while the highest score was 100.

From the obtained result, project-based learning is considered effective to improve students' cognitive abilities of fourth graders for animal life cycle lesson. The outcomes of science learning increase from sufficient category to good category. Classical learning mastery increases from less good category to excellent category.

\subsection{Discussion}

This study was conducted in grade four of SD A, SD B, and SD C in the academic year 2018/2019 involving 105 students. The learning process was carried out for two meetings, each of which was held for $2 \times 35$ minutes by applying PjBL model in science learning. This implementation consists of several stages, starting from preparation stage. In this stage, students and teachers decide some points to discuss. To reach the success of PjBL, teachers should engage students' interest and trigger their curiosity by making driving questions [11]. The next stage is planning, when students listen to the teacher's explanation about steps to make a report and gather learning materials.

The next stage is implementation. It is started by creating groups of 5 students, and subsequently design a project. Students list down some information from various sources, identify and integrate points related to the given topic. In addition, students manage the information and turn it into a real product. Moreover, there is evaluation and follow-up stage. In this stage, students write down a report and present it. Generally, students actively involved during learning activities using PjBL model.

Based on students' learning outcomes form pretest and posttest, it is concluded that there is positive effects of PjBL model implementation in science learning. The effects include students' enthusiasm during learning, students' activeness both in asking and answering questions from the teacher, and students' bravery to come forward presenting their report.

Based on the aforementioned result, there is improvement in students' cognitive abilities. This shows that project-based learning model highly affects students' learning outcomes during science learning of grade four in elementary school A and B. This result is in line with some other studies. For example, a study by Lestari et al (2018) showed that project-based learning encourages the skills of science process and students' critical thinking in Science, Technology, Engineering, and Mathematics (STEM). Through STEM project-based learning model, students are able to determine the concept of learning and linking with real-life applications [12].

In addition, Tasci (2014) in her study about the implementation of project-based learning in social science lesson for architecture students found out that project based learning approach affects academic achievement and learning permanence and learning functionality in a positive way [13]. Moreover, Chen and Yang (2019) asserted that compared to the 
traditional learning method, project-based learning has a medium to large positive effect on students' academic achievement [14].

In general, the limitation of this study is researcher's limitation related to the time as time allotment of science learning is only $2 \times 35$ minutes. It limits students particularly from finishing the project and presenting the product.

\section{Conclusion}

Based on the result of the study, the average score of students' cognitive skills in the experiment class was 72.7, while the students' in the control class was 71.9. Therefore, it can be concluded that there is a positive effect of project-based learning model on the science learning outcomes. From this general conclusion, specific conclusions are drawn as follows: (1) The average of students' learning outcome increases in science learning of grade four in elementary school A and B by implementing project-based learning, from sufficient category to excellent category. (2) There is a positive effect of project-based learning model on the science learning outcomes of fourth graders in elementary school A and B. (3) The effect of project-based learning implementation on students' science learning outcomes subsequently improves students' cognitive skills. 


\section{References}

[1] Brierton, S., Wilson, E., Kistler, M., Flowers, J., \& Jones, D. (2016). A comparison of higher order thinking skills demonstrated in synchronous and asynchronous online college discussion posts. NACTA Journal, 60 (1), 14.

[2] Musa, F., Mufti, N., Latiff. R.A., and Amin, M. Mohamed. (2012). Project-based learning (PjBL): inculcating soft skills in 21 st century workplace. Procedia - Social and Behavioral Sciences, 59 pp. 565 - 573. doi: 10.1016/j.sbspro.2012.09.315.

[3] Amamou, S., Cheniti-Belchadi, L. (2018). Tutoring In Project-Based Learning. Procedia Computer Science, 126 pp.176-185. doi: 10.1016/j.procs.2018.07.221.

[4] Dado, M., \& Bodemer, D. (2017). A review of methodological applications of social network analysis in computer-supported collaborative learning. Educational Research Review, 22, 159180. doi: 10.1016/j.edurev.2017.08.005.

[5] Lenz, B., Wells, J., \& Kingston, S. (2015). Transforming schools using project-based learning, performance assessment, and common core standards (1st ed.). San Francisco, CA: Jossey-Bass.

[6] Efstratia, D. (2014). Experiential education through project based learning. Procedia - Social and Behavioral Sciences, 152 pp.1256 - 1260. doi: 10.1016/j.sbspro.2014.09.362.

[7] Sasson, I., Yehuda, I., Malkinson, N. (2018). Fostering the skills of critical thinking and questionposing in a project-based learning environment. Thinking Skills and Creativity. doi: 10.1016/j.tsc.2018.08.001

[8] Mayilvaganana, M., Kalpanadevi, D. (2015). Cognitive Skill Analysis for Students through Problem Solving Based on Data Mining Techniques. Procedia Computer Science, 47 pp.62-75. doi: 10.1016/j.procs.2015.03.184.

[9] Mumford, M. D., Todd, E.M., Higgs, C., McIntosh, T. (2016). Cognitive skills and leadership performance: The nine critical skills. The Leadership Quarterly. doi: 10.1016/j.leaqua.2016.10.012

[10] Heineck, G. and Anger, S. (2010). The returns to cognitive abilities and personality traits in Germany. Labour Economics, 17 (3):535-546.

[11] Efstratia, D. (2014). Experiential education through project based learning. Procedia - Social and Behavioral Sciences, 152 pp.1256 - 1260. doi: 10.1016/j.sbspro.2014.09.362.

[12] Lestari, T.P., Sarwi, Sumarti, S.S. (2018). STEM-Based Project Based Learning Model to Increase Science Process and Creative Thinking Skills of 5th Grade. Journal of Primary $\begin{array}{llllll}\text { Education, } & 7 & \text { (1) } & \mathrm{pp} & \text { Retrieved }\end{array}$ https://journal.unnes.ac.id/sju/index.php/jpe/article/view/21382

[13] Tasci. B. G. (2014). Project Based Learning from Elementary School to College, Tool: Architecture. Procedia - Social and Behavioral Sciences, 186 pp. 770 - 775. doi: 10.1016/j.sbspro.2015.04.130.

[14] Chen, C.H., Yang, Y.C. (2019). Revisiting the effects of project-based learning on students' academic achievement: A meta-analysis investigating moderators. Educational Research Review 26 pp. 71-81. doi: 10.1016/j.edurev.2018.11.001. 